\title{
Contribution of Nonformal Education (NFE) in Improving English Performance
}

\author{
Budi Indra Syahdewa \\ Accounting Department, State Politeknik of Medan \\ Jl. Almamater No.1, Kampus USU, Medan 20155, North Sumatera, Indonesia \\ bisyahdewa@gmail.com
}

\begin{abstract}
This paper discusses how a nonformal English class could help students solve their basic English problems and improve their English performance. The learning process must be conducted out of the formal class. The students cannot follow the lesson normally delivered fully in English language. The participants of the course were given a specific treatment to find out the contribution of the course to their English performance. Learning materials were prepared and delivered based on the needs of the participants. An experienced tutor of English was also selected to teach the class. This experiment used pre and post test method. The result of the course shows an increasing of English performance of the participants. It can be concluded that nonformal learning activity is really required as a solution of a problem in a formal class.
\end{abstract}

Keywords: English Course, Nonformal Education, and Performance.

\section{INTRODUCTION}

Teaching English at college is surely viewed different with the one at schools. The university students who have learned English from the elementary schools until Senior High School are considerably able to follow and understand English lessons at college, then perform basic English properly. In fact, some students can follow the lessons without any problems and communicate in English fluently. But, there are quite a few students finding difficulties to study English at college. The gap of capability between the ones who can and those who cannot understand the English lesson has created some problems on the teaching and learning English in the classroom. Sometimes, a teacher has to use the translation method in the teaching process for time efficiency. A teacher has to speak more slowly, not in common, for the students who are quite slow or weak. It has made some other students get bored in the classroom.

Politeknik Negeri Medan as one of higher educational institutions in Indonesia, running diploma programs, has also put English in its curriculum. English subject was taught for six semesters but it is only four semesters, four sessions a week. English subject is presented by using Communicative Approach in which target language should be spoken all the time in the process of learning and teaching; The use of first mother tongue is not recommended. With only maximum 28 students in the classroom a teacher is expected to have time to communicate directly with the students.
In the teaching and learning process of English subject, it was found that a number of students had some difficulties to reach the expected competency. Based on the result of observation, some students have not understood or used Tenses correctly. Meanwhile, communication in English language can not be separated from the use of Tenses. The errors made by the students could sometime be explained in the classroom but some other students might not be able to understand it. [3] suggest that "the formal education has to accept the existence of the informal and nonformal education and to use them in a useful way, for teaching". We have to find a place and time out of the formal classroom in which any method of language teaching can be implemented, such as Translation Method in which students can speak in their first language in the class. Based on the significant differences found in the process of teaching and learning process at the Politeknik Negeri Medan, this study is intended to reveal the contribution of an English course as a part of Nonformal Education in improving English performance.

\section{ENGLISH COURSE AS A PART OF NONFORMAL EDUCATION}

Nonformal education can be defined as any organized educational activities, conducted out of school hours, and to give special service to the participants in achieving learning goals [1] In addition, the Indonesian Constitution about National Education System No.20/2003 article 26/1 states that the function of nonformal education towards the formal education is as substitute education, supplementary education, and complementary education. Nonformal education is more fleksible and always refers to the basic need of the participants with changes they always have. It can be implemented by the government, institutions, a group of people, or individual.

[5] describes that nonformal education as complementary education completes the ability of the participants by providing the with learning experience which is not provided in the school curriculum. As a consequence, a course may be conducted by cooperating with other parties out of schools such as courses running programs needed by the students. In this case, there should be a communication between schools and the instituions or courses running the programs about the real needs of the students. The result of the program will support the efforts of the participants to accomplish the competency stated by schools.

In a model of English course, the participants study the knowledge of English language, for example Tenses, according 
to what they really need. The learning process in a course as a nonformal education unit use teaching methods suitable on the need to solve the problems faced by the participants. The teaching method must also apply psychologial approach in which problems of the students in English are discussed openly together. The participants can freely express their feelings and problems about something unknown or understood. At the same time, the tutor/teacher in nonformal education serves their needs patiently and explain everything comprehensively so that the problems will no longer appear in the future. As [2] said "Activities in the classroom focus at all times on topics which are interesting and relevant to the students and encourage them to express their ideas, opinions, desires, emotions, and feelings".

\section{THE NEED OF NFE IN IMPROVING ENGLISH PERFORMANCE}

A formal English classroom provides students with a prepared curriculum and its materials. They are familiar with the classroom situation as well as the common process of learning and teaching of English. Students have acquired the English grammar and vocabulary but they don't want to speak English for some reasons such as feel shy, worry to make mistakes, no supporting environment for speaking English. Some of students want to speak English well; communicatively use in real life. Unfortunately, the chance they have in the classroom to improve their performance is limited and focused to English grammar over learning with traditional teaching. Eventhough the speaking skill is taught in school or university, but time is not prevalent.Therefore, their speaking skill is not improved. [6] believes that nonformal education is functioning to complete the ability of the participants by giving the experiences of learning outside the formal curriculum. This program can be conducted by the teachers involved in the formal education.

\section{METHODS}

This study is empirically conducted at the Finance and Banking Study Program, Medan State Polytechnic. The population of the study was 299 students with a sample of 20 students. Purposive sampling technique was used for this experiment study. The instrument used for this experiment is pre-test and post-test. The experimental research design is one-group-pre-test -post-test. As [6] states that the result of the treatment can be accurately identified by comparing with the pre-treament condition. The test consists of 20 questions of basic English grammar and two open questions in which the respondents answer and 2) What do you usually do on the week-end?

\section{RESUlTS AND DISCUSSION}

[4] suggest the planning stages of the training consists of 1) needs identification, 2) formulation of traning objectives, 3) preparation of training program, 4) preparation of pre-test and post test, and 5) preparation of the tutor. In the implementation of the training, the activities are: 1) executing the pre-test, 2) implementing the training program, and 3) executing the posttest.

The subjects of this research are 20 students of the Medan State Polytechnic, North Sumatera, Indonesia studying in Banking and Finance Study Program. As students of semester 4 in higher education, normally they have been studying English at least 8 years, counted from junior high school. They have studied English grammar and acquired some English vocabulary. It was found that their English performance in the formal classroom was not as expected.

In this experiment, the tutor has identified the weaknesses of the students and hopefully could do the course effectively to help students improve their English performance. The course is conducted in five two-hour meetings.

The teaching method applied for this English course is any method that can help the students understand quickly the lessons. The atmosphere of the course is created as friendly as possible so that the students would like to participate and ask for anything they don't understand about the lessons.

For this experiment Pre-Test and Post-Test are given and the findings as follow:

1) The questions are made to find out the participants' knowledge about English basic grammar. The following is the questions and the results of the pre-test and post-test.

The participants were instructed to find any error in the sentences and has to write the correct versions. Example: I am study English now. (studying)

TABLE I. LIST OF QUESTIONS AND RESUlTS OF PRE-TEST AND POSTTEST ENGLISH COURSE

\begin{tabular}{clcc}
\hline NO & \multicolumn{1}{c}{ QUESTIONS } & $\begin{array}{c}\text { PRE-TEST CORRECT } \\
\text { ANSWERS OF 20 } \\
\text { PARTICIPANTS }\end{array}$ & POST-TEST \\
\hline 1 & Are you believe in God? & 5 & 20 \\
2 & She usually woke up at five o'clock every morning. & 2 & 15 \\
3 & But this morning, she gets up at six o'clock. & 6 & 18 \\
4 & Tom doesn't come to school last week. & 10 & 15 \\
5 & He is sick when I came to see him. & 12 & 16 \\
6 & John's father teach him how to drive when he was 17. & 10 & 16 \\
7 & He does not shave this morning because he was busy. & 7 & 12 \\
8 & Barry needs some money so he sold his motorcycle. & 3 & 11 \\
9 & George throws the ball to Sam who caught it. & 0 & 9 \\
10 & According to the weather forecast it is rain tomorrow. & 0 & 10 \\
11 & What did you doing at 9 o'clock last night? & 0 & 10 \\
12 & When Tom arrive, we were having dinner. & 10 & 19 \\
13 & How long did you stayed there? & 7 & 20 \\
14 & I study at the Polytechnic. My brother study at the & 3 & 18 \\
& university. & 12 & 20 \\
15 & Where does she comes from? & 1 & 19 \\
16 & In summer Tom usually play tennis once a week. & 2 & 20 \\
17 & Water boiles at 100 degrees centigrade. & 13 & 20 \\
18 & John doesn't goes to the cinema very often & 3 & 15 \\
19 & Please don't make so much noise. I sleeping. & 9 & 16 \\
20 & Ann spent a lot of money yesterday. She buys a dress & & \\
\hline & which cost $\$ 100$. & & \\
\hline
\end{tabular}

- The result of the pre-test found out that in average only $28.4 \%$ of the questions can be answered correctly.

- The post-test result showed that in average the students can achieve $78.7 \%$ correct answers. 
2) The question for English Performance: "What activities did you do this morning until you arrived at school?", and "What do you usually do on the week-end?"

This is an example of a participant's answer for ther pretest:

I woke up in the morning at $05.20 \mathrm{am}$. After that I pray for a minute. Then I go to the bathroom to take a bath. After take a bath, I wear my clothes. Them I am take a breakfast. After take breakfast, I am talking with my mother about 15 minutes. Then I go to the college.

The result of pre-test shows that only 25 percent of the participant performed their English correctly while the posttest result indicates that $60 \%$ of the participants could write the answer correctly.

In the process of running the course, the tutor encouraged participants to ask anything they don't understand either in English or in their mothertongue, Bahasa Indonesia; They don't have to be shy or worry of making mistakes. The tutor also gave a lot of exercises or practices of speaking English in the classroom and as homeworks.

It is very interesting to find out that all of the participants admitted that they have studied all of the materials given before they came to the higher education. It is also the fact that they hardly speak English in their daily life, including in the formal classroom.

\section{CONCLUSION}

Teachers of English language should be aware when there is a gap in English competence and performance of the students in the classroom. They have to identify the ability of every student in the target language and an effective method of teaching the target language has to be applied in order to achieve the goals. A course out of the formal class should be implemented as a way to help students solve their problems on basic English knowledge. In conclusion, a course as part of nonformal education contributes in improving the English performance

\section{REFERENCES}

[1] Kamil, M, Pendidikan Nonformal: Pengembangan Melalui Pusat Kegiatan Belajar Mengajar (PKBM) di Indonesia. Bandung: Alfabeta, 2009.

[2] Krashen, S, The Natural Approach. San Fransisco: Alemany Press, 1983.

[3] Moldovan, O. and Bocos-Bintintan, V, The Necessity of Reconsidering the Concept of Nonformal Education. Procedia-Social and Behavioral Sciences 209, pp. 337-343, 2015.

[4] Sudjana, D, Sistem \& Manajemen Pelatihan: Teori \& Applikasi. Bandung: Falah Production, 2007

[5] Sudjana, D, Pendidikan Non Formal. Bandung: Falah, 2001

[6] Sugiono, Metode Kuantitatif, Kualitatif dan R\&D. Bandung:Alfabeta, 2010 . 